\title{
Can Social Media Save a Neighborhood Organization?
}

Bonnie J. Johnson

Associate Professor, Department of Urban Planning, University of Kansas

1465 Jayhawk Blvd., Room 418

Lawrence, KS 66045-7626

USA

785-864-7147

bojojohn@ku.edu

Germaine R. Halegoua

Assistant Professor, Department of Film and Media Studies, University of Kansas

225 Oldfather Studios

1621 W. 9th St

Lawrence, KS 66044

USA

785.864.1931

grhalegoua@ku.edu

Prepared for International Conference Using ICT, Social Media and Mobile Technologies to Foster Self-Organization in Urban and Neighbourhood Governance, May 16-17, 2013, Delft University of Technology, Delft, The Netherlands 


\begin{abstract}
The purpose of this research is to evaluate the success of social media as a community engagement tool at the neighborhood level and, thus, expand on existing theories and practices in regards to social media and place-based communities. We found a neighborhood association that was considering dismantling after 38 years due to low participation rates. In a last effort to rebuild, they were willing to try social media platforms like Facebook and Twitter. After the initial launch and promotion of the online tools, they gained no comments, responses, or retweets, and only 5 "likes", 3 Twitter followers, and 2 people for the email listserv out of a possible 550 households. We conducted a survey with neighborhood residents in order to understand why members of the neighborhood did not join these social media networks and why they were not engaged with the neighborhood association in general.
\end{abstract}

Our findings indicate that previous research recommending multiple types of communication to reach everyone in a neighborhood is valid but neighborhood organizations should also target their communication to maximize often limited resources. In our case study, the neighbors who said social media were good ways to communicate with the neighborhood were also the ones who said they wanted a neighborhood association. This was not the case for those choosing email or mail options. We also found a mismatch between "neighborly" ties and the more intimate ties associated with "friends" on social media, desires for inclusive communication, and expectations regarding face-to-face communication within a neighborhood setting. These results show the different roles of neighborhood organizations (sociability versus political representation or a mix of both) and how social media fits with these different roles. Based on the survey results, advice for using social media to revive a neighborhood organization is offered. 


\section{Introduction}

There could be a myriad of reasons for a failing neighborhood organization: a lack of purpose (McClenahan, 1929), structure (Ohmer, 2008), or "battle" to be won (Hillier, 2002), members' dissatisfaction with the organization (Perkins \& Long, 2002), lack of leadership (Chavis \& Wandersman, 1990), competition for people's time from other organizations or entertainments (Putnam, 2000), poor physical design of the neighborhood (no walkability, low density, no front porches, unattractive streetscapes) (Brown \& Cropper, 2007), highly selfsufficient households (Riger \& Lavrakas, 1981), and the rise of "communities of interest" over "communities of place" (Roberts, Smith, \& Pollock, 2002). Also, declining participation can be linked to a lack of a sense of community and related issues of low levels of individual and/or collective efficacy, neighboring behaviors, place attachment, communitarianism, confidence in the future of the neighborhood, or civic participation in general (Chavis \& Wandersman, 1990; Perkins \& Long, 2002). The research on communities and Internet use, email lists, websites, and social media are hopeful about online connections reinforcing or augmenting offline interactions in place-based communities (Arnold, 2003; Carroll \& Rosson, 2003; De Cindio, Gentile, Grew, \& Redolfi, 2003; Evans-Cowley \& Hollander, 2010; Hampton \& Wellman, 2003; K. N. Hampton, 2007; A. L. Kavanaugh et al., 2007; B. J. Kim, Kavanaugh, \& Hult, 2011). The use of social media is presented in urban planning and information and communication technology literatures (with some caveats) as a low cost, efficient, convenient, easy, and immediate way of communicating with people within place-based communities about issues and events (Evans-Cowley, 2010; Evans-Cowley \& Hollander, 2010; A. L. Kavanaugh et al., 2007; B. J. Kim, Kavanaugh, \& Hult, 2007; B. J. Kim et al., 2011; Mandarano, Meenar, \& Steins, 2010; Shah, Kwak, \& Holbert, 2001). An author of one such article wrote, "while writing this article one of the authors communicated with three neighbors via Facebook to plan a potluck dinner" (Evans-Cowley \& Hollander, 2010, p. 397). It sounded so great, a neighborhood organization gave it a try and this study follows the results. 
What happens when a neighborhood organization turns to social media to re-energize and rejuvenate itself? How useful is social media as a tool for neighborhood engagement? We conducted a study with an established neighborhood whose neighborhood association had seen better days. In the last 10 years, participation rates tumbled from over 100 to single digits. The association was considering dismantling after 38 years. However, the last remaining active officers and steering committee members decided to turn to social media platforms like Facebook and Twitter in order to re-build neighborhood ties and ultimately the neighborhood association. They created a Facebook page, Twitter account, and asked people to email if they wanted to join a neighborhood emailing list. After the initial launch and promotion of these online tools, they gained no comments, responses, or retweets, and garnered only 5 "likes", 3 Twitter followers, and 2 people for the email listserv out of a possible 550 households. We conducted a survey with neighborhood residents in order to understand why members of the neighborhood did not join these social media networks and why they were not engaged with the neighborhood association in general.

This study seeks to shed light on social media as a tool for reviving a failing neighborhood organization and thus help define its benefits and limitations within a neighborhood context. We begin with a look at the literature on neighborhood organizing summarizing what accounts for low participation rates and what neighborhood organizations can do to garner support. We then address previous findings about information and communication technologies (ICTs) and their usefulness to place-based groups like neighborhoods. Next, the case study neighborhood is introduced along with the methodology. The results are discussed in regards to those who seem supportive of having a neighborhood organization and their preferred modes of communication. Some preliminary implications, limitations, and recommendations for social media use by neighborhood organizations are then offered. 


\section{Sense of Community and Neighborhood Organizing}

"Neighborhood" is "a social and geographic concept" (Coulton, Jennings, \& Chane, 2012, p. 40) and highly susceptible to "subjective perceptions" (Martinez, Black, \& Starr, 2002, p. 25). The term "neighborhood" has strong connotations related to democratic values in the United States: participation, the great melting pot, and the heroics of common people (Looker, 2010). Neighborhoods can have the reputation of cultivating such strong interests that their self-interests compete with the common good of their larger communities, but then there is the other extreme of disinterested and/or disenfranchised neighborhoods (McKenzie, 1922).

People have many relationships outside of their neighborhoods and technology (communication and transportation) makes those easier to pursue than ever. Kotler (1969, p. 9) explains, "The neighborhood was never a sufficient unit for friendship and social intercourse." However, Unger and Wandersman (1985, p. 141) maintain that "neighbors and neighborhoods still have a very important place in many individuals' lives." "The close spatial location of neighbors makes them unique to perform functions which other network members would find difficult" (Unger \& Wandersman, 1985, p. 141). Examples are emotional support, occasional day care, security, or organizing to solve a local problem. Neighborhoods can take on a variety of roles: sociability arena, interpersonal influence center, mutual aid, organizational base, and status arena (Warren, 1977).

While recognizing the social nature of neighborhoods, Kotler tried to create a definition of "neighborhood" that explained what a neighborhood was without overlapping with other social or organizational constructs. His definition is "a political settlement of small territory and familiar association, whose absolute property is its capacity for deliberative democracy" (Kotler, 1969, p. 2). Kotler sees neighborhoods as key members of local governance structures and counterweights to other political interests. This points to the role of neighborhoods as training grounds for democracy and voluntary local organizations as important links in urban service delivery from health promotion to crime prevention (Chavis \& Wandersman, 1990; Olson, 1982). 
An individual's sense of community, empowerment, relationships with neighbors along with positive associations with one's block/neighborhood can all influence formation and participation in local groups (Chavis \& Wandersman, 1990). Turning individual empowerment into group empowerment requires leadership and an ongoing track record of success (Chavis \& Wandersman, 1990; Florin \& Wandersman, 1990; Itzhaky, 1995).

Its takes time to establish a neighborhood organization with a reputation for effectiveness and participants and leaders that are well connected within the neighborhood and beyond (Backman \& Smith, 2000; Unger \& Wandersman, 1985). Successful neighborhood organizations have leaders who are good at "one-to-ones" where they meet, listen to, and get to know potential participants, ultimately turning them into active participants (Christens, 2010). Leaders with access to other community services (advice, money, volunteers) can more efficiently address any neighborhood issues versus spending time just maintaining the organization (Unger \& Wandersman, 1985). In other cases, neighborhood organizations are all "leadership" in that they rely on the work of a few because there is no larger "we" feeling in the neighborhood (McKenzie, 1921; Silver, 1985; Tannenbaum, 1948).

"Place" and an attachment or loyalty to one's neighborhood is another ingredient in forming and keeping neighborhood organizations (Itzhaky, 1995; Perkins \& Long, 2002). Often, neighborhoods organize because they are facing a threat (real or perceived) (Chavis \& Wandersman, 1990). Having an issue to rally around is good to start but without some larger sense of community and relationships, the organization is hard to maintain after the threat passes or when people tire of being on high alert (Hillier, 2002). On a related note, if a neighborhood is full of very self-sufficient residents, there will be little push for a neighborhood organization either (Riger \& Lavrakas, 1981).

Sense of community has been measured by any number of means: bond to the community, empowerment, control, safe place for children, satisfaction with the neighborhood, expecting to stay in the neighborhood for a number of years, walkability, and political efficacy 
(Chavis \& Wandersman, 1990; Glynn, 1981; Martinez et al., 2002; Perkins \& Long, 2002;

Peterson et al., 2008). Each is an aspect of "sense of community" and is a building block for long-term neighborhood organizations. Sense of community can also include "neighboring behaviors" that range from knowing the names of one's neighbors to being comfortable borrowing a tool or keeping an eye on a neighbor's children (Doolittle \& MacDonald, 1978; Warren, 1977).

Aside from neighborhoods providing "mutual aid" Kotler (1969) emphasizes that a neighborhood is not a neighborhood unless it has a name and boundaries. These boundaries can change over time and residents can define their neighborhood differently (Taylor, 2012). It is notable that those who take a larger view when defining their neighborhood tend to be people who are more engaged with the neighborhood (Coulton et al., 2012). Having a name and boundaries are helpful when moving from informal relationships to more formal ones and engaging with local government (Taylor, Gottfredson, \& Brower, 1984). Perkins and Long (2002) note how sense of community and neighboring behaviors are informal but when they turn into collective efficacy and citizen participation then they create an opening for formal organizations. Ohmer (2008) provides an overview of what an empowering organization or empowered organization looks like. In general, they have democratic processes, a formal structure with clear tasks, sociability, order, and shared responsibilities. They also are good at making participation easy for members and are able to achieve organization goals and influence community decision-makers. As successful neighborhood organizations must connect with neighbors and with the larger community, it is easy to see why they would be attracted to social media as a tool for efficiently building and maintaining networks.

\section{Use of Social Media or ICTs for place-based organizations: Findings and Strategies}

Researchers, technology designers, and urban planners have noted the potential that social media and digital technologies have for creating "information grounds" and/or means of connection and communication within neighborhoods. Social media is promising as a way for 
community organizers and urban planners to reach people quickly saving time, money, and the energy of volunteers (A. L. Kavanaugh et al., 2007, p. 393; B. J. Kim et al., 2007, p. 208). However, we need further research on how and under what conditions and contexts digital applications, like social media, are successful (Evans-Cowley \& Hollander, 2010; Meredith, Ewing, \& Thomas, 2004; Pinkett, 2003). As many researchers have been careful to note, access to information technologies will not automatically create or incubate social networks where none previously existed (Foth, 2006a, 2006b; Gaved \& Foth, 2006; K. Hampton, 2003; Hampton \& Wellman, 2003) and they must mesh with local contexts in order to foster engagement (Ball-Rokeach, Kim, \& Matei, 2001; Postill, 2008).

Findings from community informatics studies are tempered with both opportunities and risks associated with community networking (Carroll, 2012; Gurstein, 2004; Schuler, 1996). However, this literature generally begins with the perspective that communities can be "empowered" and "enabled" by communication technologies if they adapt and design digital tools and if residents and communities transform themselves to become authors and audiences "in the unending and increasingly rapid flow of information within and among communities and between communities and the larger society." (Gurstein, 2004, p. 2). Although technologies like the internet and mobile phones aid communication across vast geographic distances, they have been found to enhance local relationships and communities of place as well in terms of coordination and mobilization, social capital, and interpersonal or collective connection and bonding (Ellison, Steinfield, \& Lampe, 2006; A. Kavanaugh \& Patterson, 2002; Pigg \& Crank, 2004; Wellman, 1999; Wellman \& Hampton, 1999). Studies of community networks find that ICTs are often employed as ways to maintain, enhance, and create opportunities for face to face interactions (Carroll, 2012; Cooperrider \& Avital, 2004; Hampton \& Wellman, 1999; Hollan \& Stornetta, 1992). For example, Ellison, Steinfield, and Lampe (2006) found that social networking sites like Facebook could also enhance place-based communities and increased social capital within places such as a college campus. In the study of Netville, Hampton (2003, 
p. 420) argues that the listserv in particular provided residents with "specific cultural capital in terms of knowledge of local events, local services, and the opinions and activities of other residents" which lead to face to face interaction to share information. However, Hampton, Lee, and Her (2011) found that place-based relationships have slightly less resonance for social media users, which might be linked to previous findings (K. Hampton, 2007) that residents with few neighborhood ties are more likely to use social media in their daily lives (Hampton et al., 2011, p. 1046).

In an empirically grounded study on social capital within "wired" neighborhoods, Hampton and Wellman (2003) found that weak not strong ties benefit from ICT implementation and use within neighborhoods. ICTs such as email, forums, and listservs help to create large, dense networks of weak ties, and wired residents generally had more neighborhood connections than non-wired residents. Additionally ICTs and the communication that takes place over ICTs were found to facilitate collective action and community organizing by creating large dense networks of relatively weak social ties. Several researchers have argued that neighborhoods with ICTs were better equipped to address local concerns. Pattavina, Pierce, and Saiz (2002) illustrate how gathering and archiving neighborhood-level crime data can build local knowledge and more accurate understandings of crime and crime prevention strategies. Scholars note that online community networks are readily utilized to address local or community issues and spaces where co-located community members can work collaboratively to solve problems (Carroll, 2012; Foth \& Brereton, 2004; K. Hampton, 2003). In Netville, information flows were improved inexpensively (in terms of time, cost, effort), and listservs and forums created new visibilities for networks of action. "Neighborly" actions online were read by participants as residents having an investment in maintaining community relations and positive social ties (K. Hampton, 2003, p. 425), or what Postman (1999) might recognize as "common obligation". However, during moments of stability, when Netville was not dealing with a crisis or 
a shared issue or cause for concern, activity on the neighborhood message boards and email lists decreased.

Community informatics projects that utilize digital technologies for the dissemination of local news and stories have been linked to increased neighborhood engagement. Several scholars (Ball-Rokeach et al., 2001; Y.-C. Kim \& Ball-Rokeach, 2006) have recognized that the practice of sharing stories about local issues, events, and news can augment and/or enable neighborhood engagement and efficacy. Furthermore, Kim and Ball-Rokeach (2006) have suggested that the visibility of and ability to participate in local stories and storytelling practices, and the visibility of shared neighborhood concerns may encourage other people to talk about neighborhood issues, experiences, and news, and thus lead to increased neighborhood engagement and prolonged maintenance of this engagement. The participants in Chen et al. (2012) noted that the most desirable way to gain access to neighborhood stories and local news was via digital technologies. Although social media or other "Web 2.0" technologies seem useful for creating networks of visibility for digital storytelling and local, collaborative news dissemination, the participants in Chen et al. (2012) specifically noted that they would prefer emailed newsletters or e-newsletter digests as a means of communication.

Nevertheless, it seems that a minority of residents in the United States engage with neighbors or neighborhood associations via digital technologies. A national survey conducted by Pew in 2009 ("Neighbors Online") found that face to face and phone calls were the most common methods of communicating with neighbors. Among those who knew all of their neighbors by name, $70 \%$ have discussed community issues with neighbors in person, compared with just $12 \%$ of participants who did not know any of their neighbors. Those who knew their neighbors also communicated by phone and email more often than those who did not. However, people who do not know their neighbors by name were just as likely to keep up with community events via blog or to join a community focused social networking site or discussion group. While participants surveyed by Pew used a range of approaches to 
communicate with neighbors, approximately one in five Americans used digital tools (such as email and mailing lists, social media, blogs, and websites) to communicate with neighbors and monitor community developments (Smith, 2010). Parents were more likely than non-parents to meet with neighbors face to face. The Pew researchers found that email was the most common digital means of communication between neighbors. Email use was most common among 65 and older, followed by 30-49 and 50-64 age ranges respectively, with more parents than nonparents reaching out to neighbors via email. The lowest rate of email between neighbors was among 18-29 year olds. Social networking sites (SNS) were most common among 18-29 and 30-49 year olds (both age ranges were equally likely to use SNS), half as much at 50+. Other than age, there is little variation. However, only a small percentage $(\sim 14 \%)$ of SNS users used social media to communicate with neighbors. In sum, social media sounds promising but it may be still in its infancy in terms of widespread adoption and it may not match well with neighborhood organizing.

\section{Background and Case Study: Indian Hills Neighborhood and Social Media Presence}

The case study neighborhood is Indian Hills and its neighborhood association is the Indian Hills Neighborhood Association, also known by its initials, IHNA. The neighborhood is located in the middle, southern part of the City of Lawrence, Kansas (see map 1). Lawrence's 2010 population was 87,643 while IHNA's was 1,527 (see Table 1). Founded in 1854, Lawrence is the county seat and home to the University of Kansas and Haskell Indian Nations University. Because of the universities, Lawrence is a young community (8\% in the "65 or over" category) and Indian Hills has an older demographic (15\% are "65 or over"). The neighborhood was one of the first expansions of the city in a southerly direction in the early 1950s, growing in size into the later 1960s (Indian Hills Neighborhood Association, 2003). Previous highway-oriented commercial businesses along 23rd Street slowly became in-town commercial businesses as the city grew to the south. The neighborhood itself is predominantly single-family homes with some duplexes, tri-plexes, and four-plexes. Common housing types are ranches, split-levels, and 
some Cape Cod style homes. The neighborhood is largely on a grid with 6 cul-de-sacs off of busy Louisiana Street and only 7 cul-de-sacs internal to the neighborhood (see Map 2).

Although on a modified grid, not all homes have access to an adjacent sidewalk. An elementary school and middle school are across Louisiana Street from the neighborhood to the east. There are 2 grocery stores, a hardware store, and other commercial businesses within walking distance to the north. To the west is a linear park named Naismith Valley Park with a walking and biking trail and across Louisiana Street, next to the schools, is Broken Arrow Park with a playground and ball fields. There are 3 churches in the neighborhood.

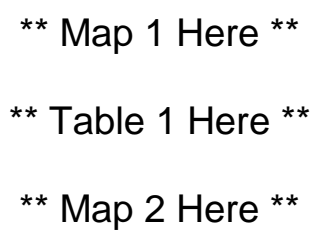

In 1968, residents next to Naismith Valley Creek on Arkansas Street organized to protest the construction of a large apartment complex in the Naismith Valley floodplain. Later on, that core group of neighbors expanded and officially became the Indian Hills Neighborhood Association in 1974 (Indian Hills Neighborhood Association, 1985). At their founding meeting in 1974, the IHNA agenda was to make sure the creek channel in Naismith Valley Park was kept clear and being involved with plans for a bicycle/foot path in the park (Indian Hills Neighborhood Association, 1974). From 1977 to 1981 , IHNA was inactive until being reorganized in 1981 and then fully revived in 1986. The annual meeting in the Fall of 1994 had 59 attendees, the Fall 1999 meeting had 38, and in 2006 there were 17 participants. The last annual Fall meeting was in 2010 with 28 attendees. In addition to the annual Fall meeting, IHNA was known for hosting a night of luminaria (candles in paper bags along the streets of the neighborhood). Luminaria were always displayed the Sunday before Christmas and IHNA would supply the paper sacks and sand (for stability and to hold the candles in the bottom of the bags). It was common for residents of Lawrence to drive through the neighborhood that night to see the lights. This event started at about 500 candles and would expand to 4,000 when the weather was good (Indian 
Hills Neighborhood Association, 2004). However, this tradition ended in 2008 when people decided there were not enough participants. After the potluck in 2010, there were not enough volunteers to plan meetings, hold elections, and put together and fund any more newsletters. In the past, IHNA mailed newsletters to 550 households and as late as 2003 had 150 dues paying members (Indian Hills Neighborhood Association, 2003). IHNA was one of the founding members of the Lawrence Association of Neighborhoods (LAN). LAN was founded in 1987 and is an umbrella organization made up of 11 neighborhood associations. Part of LAN's founding and IHNA's revival in 1986 was due to a sense in the community that neighborhoods should form a coalition to counteract what was seen at the time as an overly influential development community within Lawrence (Lopes, 2001). A founding member of IHNA and LAN refers to this time as "the revolt" (Indian Hills Neighborhood Association, 1998).

Until recently, IHNA collected annual dues from members and held annual elections of officers (Chair, Vice-chair, Secretary, Treasurer, and a Steering Committee). The last set of officers was elected in 2010. After seeing participation rates tumble and being unable to muster volunteers to serve as officers or to organize events, in February of 2012, the remaining members of the Steering Committee and officers ( 5 residents) met to determine whether the organization should be disbanded. To revive the organization, they decided they would try social media to better communicate with members and hopefully interest a new generation in neighborhood involvement. At that meeting, the last elected Chair of IHNA, Bonnie Johnson (one of the authors of this article) proposed an "experiment" to see whether social media could turn around a failing neighborhood association and the committee agreed to the project.

On May 6, 2012, the Facebook and Twitter pages went live and remain online to date. On May 11th, emails went to the 16 residents who had been active in the past inviting them to "like" the Facebook page and/or to "follow" IHNA on Twitter. This email generated 3 "likes" on Facebook and 2 Twitter followers. Between May 13 - 16, 550 doorhangers (printed cards with a hole cut out of the top to make them easy to hang on the doorknobs of residents' front doors) 
were delivered to households in the neighborhood announcing the Facebook page, Twitter handle, and email address where residents could sign up to be on an email list. The doorhanger also announced the remaining annual event that still generates interest, the Neighborhood Garage Sale Day set for June 2, 2012. The doorhangers generated 2 more "likes" on Facebook and 1 additional Twitter follower and 2 requests to be added to the email list. All of this occurred May 11 - 18, 2012. Twenty-three houses participated in the annual garage sale day. The original Facebook page utilized the standard Facebook "groups" template and announced the garage sale event. It had basic information about IHNA, a photo of the entry sign to the Indian Hills subdivision, and a map of the neighborhood boundaries. In July, August, and September of 2012, more photos from the 2010 IHNA potluck and content about the history of the neighborhood were added. A neighborhood meeting was announced in September via Facebook, Twitter, and an email was sent to the usual 16 email participants plus the 2 new participants generated by the doorhangers. Seven people attended the September 25, 2012 meeting, but none were new people. In January of 2013, a survey was mailed to neighborhood residents to assess why the social media outreach had not been more effective. Since the survey was sent out, three additional residents "liked" the Facebook page, but the Twitter feed has gained no new followers.

\section{Methods}

A questionnaire with a self-addressed stamped envelope was mailed to each of the 573 households within the boundaries of the IHNA on January 24, 2013. Three were returned because the dwellings were vacant. To help boost return rates, a postcard was mailed January 3, 2013 letting residents know a survey was coming (Dillman, 2000). Out of 570 valid addresses, 212 surveys were returned for a return rate of $37 \%$. The survey questions asked respondents general demographic information, how long they had lived in the neighborhood, their sense of belonging to the neighborhood and larger community, neighborhood boundaries and name, any neighborhood issues, their civic participation, what might inhibit their 
involvement in a neighborhood association, and how they would prefer to communicate (or not) with a neighborhood association and with their neighbors. The survey used and modified questions from previous studies on neighborhood organizations and sense of community (Chavis \& Wandersman, 1990; Coulton et al., 2012; Glynn, 1981; Hampton et al., 2011; Martinez et al., 2002; Perkins \& Long, 2002; Saguaro Seminar, 2000; Sigmon, Whitcomb, \& Snyder, 2002). Surveys were anonymous unless the person indicated that we could contact him or her for a future interview.

To sort through all of the possible influences on sense of community and successful neighborhood organizations, a transactional framework was used to create the multiple regression models for this study. In psychology and environmental psychology, there are researchers who advocate a transactional world view with a holistic focus on the study of people, time, and environment together in order to understand phenomena (Altman \& Rogoff, 1987; Werner, Brown, \& Altman, 2002). Because this study examines neighborhood organizing and social media communication, the transactional framework Hesse, Werner, and Altman (1988) propose to study computer-mediated communication is particularly applicable. The different aspects of sense of community and neighborhood organizing are categorized based on time, person, and environment to understand what might be happening with the subject neighborhood. Hesse, Werner, and Altman (1988, p. 148) note, "interaction cannot be understood - nor can problems be remediated - except as a confluence of people, context, and temporal qualities." "Time" incorporates the length of events and relationships as well as intervals between recurring events and sequencing. "Person" can include their personal, psychological, and demographic characteristics. Lastly, "environment" includes social context and one's physical environment (Hesse, Werner, and Altman, 1988). With this framework in mind, multiple regression models are used to examine what factors seem to be affecting whether people think the neighborhood should have a neighborhood association or not. The dependent variable uses responses to the survey item "My neighborhood should have a 
neighborhood organization" and agreement was measured on a scale from 1 to 5 with 1 being "Strongly Disagree" and 5 "Strongly Agree". The independent or predictor variables were chosen based on the neighborhood organizing literature review and the transactional framework of Hesse, Werner, and Altman (1988) (see Table 2).

** Table 2 Here **

To help understand the results of the regression models and provide further insight into when and how to use social media for neighborhood communication, responses to the open ended question, "Do you think Facebook and/or Twitter are good ways to communicate with the neighborhood? Why/ why not?" were examined. The analysis consists of open and axial coding of the responses from which key themes were identified and used to analyze the data (Cresswell, 2007; Strauss \& Corbin, 1990). Also included in the results are simple percentages to further understand the neighborhood dynamic.

\section{Results}

212 surveys were returned representing 212 households and a population of 471 . Of that 471 population, $17 \%$ are children under the age of 18 . Those who responded to the survey range in age from 20 to 91 with a mean of 58 and standard deviation of $17(n=199) .97 \%$ are white and $.5 \%$ are Asian or Pacific Islander and $1 \%$ are Native American $(n=201)$. 59\% were employed and $30 \%$ were retired $(n=211)$. Length of residency goes from a few months up to 55 years and a mean of 19 years and standard deviation of $15(n=211)$. The majority $(59 \%)$ think they will be in the neighborhood for at least 5 more years, but 26\% "Don't know" $(n=212)$. The overwhelming majority own the place where they live which is a single-family home (96\%, $\mathrm{n}$ $=212$ ) and the other $4 \%$ rent and live in $1 / 2$ of a duplex. $24 \%$ out of 212 households have children under the age of $18.70 \%$ of respondents $(n=212)$ have bachelor's degrees or above. In terms of computer usage, $86 \%(n=212)$ spend an hour or more on the Internet or email (outside of work) in a typical week. In addition, the survey asked people to pick the 3 best ways for "the neighborhood to communicate with you." The choices and associated percentages from 
most chosen to least are as follows: Mail $(69 \%, n=212)$, Email $(51 \%)$, Doorhangers $(41 \%)$, Telephone (25\%), Facebook (20\%), Word of mouth (19\%), Website (14\%), Google+ (3\%), Twitter (1\%), Blog (1\%), Mobile App (1\%), MySpace (0\%), and LinkedIn (0\%). When asked if they knew that IHNA had a Facebook page, only $9 \%(n=208)$ said yes and 3\% $(n=191)$ said they were aware of the Twitter feed.

The multiple regression model was first run with a complete set of variables covering different aspects of time, environment, and personal characteristics. The R squared was .38 and three variables were significant and positively related to having a neighborhood organization (Neighborhood Efficacy, Trust IHNA, and Neighborhood Does Well) (Table 3). These three variables were then put into a parsimonious model (Table 4) which resulted in an $R$ squared of .36 with all variables significant. With this model in place, it was rerun three times inserting a different preferred type of neighborhood communication each time (social media, email, and then mail). Table 5 shows the results with the Social Media variable. The R squared increased to .38 and all four variables were positive and significant. Table 6 indicates that when Social Media is removed and replaced with Email as the preferred type of communication, the R squared goes back to .36 and all variables are significant except for the Email variable. Lastly, the model is run with Mail as the preferred communication type. In Table 7 it shows the R squared going up to .37 and all of the variables are significant but the Mail variable is significant and negative indicating that those who chose the mail option tended to be lower on agreement with the statement that "My neighborhood should have a neighborhood organization."

\footnotetext{
** Table 3 **

** Table 4 **

** Table 5 **

** Table 6 **

** Table 7 **
} 
Is social media a good way to communicate with the neighborhood?

When asked whether social media such as Facebook and Twitter were good ways to communicate with the neighborhood, survey participants indicated various responses. People indicated who they would like to communicate with over social media and under what conditions and contexts social media was understood to be a positive, negative, or potential way of communicating. Overall, the responses to the open ended question, "Do you think Facebook and/or Twitter are good ways to communicate with the neighborhood? Why/why not?" were coded into four categories which follow with their associated percentages: Yes (25\%), No (41\%), Maybe (13\%), and Don't know/ not sure $(4 \%)(n=177)$. Below are further analyses of the written responses placed within the transactional framework (time, environment, and person) (Hesse, Werner, and Altman, 1988).

Some respondents considered social media to be a meaningful way to communicate and their comments are included here and below in quotes. People who said yes without qualification noted that social media were convenient, cost effective, not labor intensive, "easy" ways to stay connected and receive up to date information, and allowed for "instant" or "immediate" communication. All of these comments relate to "time" in terms of time saved for leaders and participants and in terms of being able to get relevant information to people quickly. A related (and rather sizable) category of respondents were participants who noted social media use within the neighborhood as potentially beneficial if used under the proper conditions. This relates to the "environment" in which social media is used. Respondents cautioned that if the neighborhood association used Facebook or Twitter to communicate then it would have to be done "correctly", meaning that it would have to be regularly updated, full of interesting and relevant content, have a base of active participants who were invested in the site, and "season it with an occasional dash of indesputible (sic) humor." The final category in the transactional framework is "the person" and a common concern of respondents was making sure people knew about the social media sites and could access and use them. They noted that even if a 
neighborhood Facebook or Twitter page existed, there is no guarantee that members of the community would be able to find it, or would be aware of the neighborhood's social media presence.

Social Media, Neighborhood, and Time

While recognizing that social media can save time and allow for "immediate" communication, residents also voiced complaints about using social media in general and it being a waste of time, intrusive, or annoying. A few respondents mentioned that they were already "super saturated" or overwhelmed with Facebook pages and requests. In this vein, one resident mentioned that: "Maybe - only if important updates are posted. If I were to get constant emails about posts/updates I would probably not take them seriously. . ."

Social Media, Neighborhood, and Environmental Context

Factors such as the perceived size and scale of the neighborhood and the number of residents an individual did not already know were referenced as reasons to avoid social media for neighborhood communication. A few residents noted that they only use social media, such as Facebook, to communicate with people they already knew or already had ties with. These residents noted that the Indian Hills neighborhood did not feel like a close knit group, therefore they would not want to use Facebook in order to communicate with the neighborhood. Representative responses include: "No, I personally limit facebook to a limited close group. Any other use is an intrusion on my space. le, not signed onto facebook for any company or commercial companies. .." "If the neighborhood felt smaller and safer I'd say facebook. But I don't feel comfortable having people in the neighborhood see my facebook. It is too big to feel like a tight knit neighborhood." Some residents noted that they would use Facebook to communicate with neighbors who they already knew, and some residents noted that they already use Facebook to communicate with neighbors in their social networks/circles.

A few participants mentioned that social media was a tool to communicate with people in geographically distant locations and not those who lived in nearby. Several participants shared 
this perspective regarding social media: "Not really, because 'neighborhood' is so associated w/ physical space." Additionally, these participants noted that neighborhood associations and neighbors should take advantage of shared geographic proximity in order to connect. Events and face to face contact were seen as "places", moments, or sites through which the neighborhood should communicate and connect. For example: "Use facebook to contact so many others who live far away or that one might never/rarely see or talk to if not for facebook. Neighborhoods should have in-person contact or fun events to attend for people to get to know one another"; "Face to face communication is best with people close by". The small size of the neighborhood and its physicality were read as reasons to question the neighborhood use of social media and to support analog forms of communication that required walking around the neighborhood, delivering information door to door or face to face. For example, one resident noted: "Yes \& No. As a small geographical area, flyers would be more effective at reaching people who don't already know the other people in the area, or who don't have access to the internet."

Social Media, Neighborhood, and Person-fit

The majority of respondents to the open ended question was hesitant about, or preferred not to use social media for neighborhood communication. Several respondents mentioned unequal access to social media and the exclusion of some people from neighborhood communication as key reasons why services like Facebook and Twitter were not good ways to communicate with the neighborhood. This trope of exclusion, inequality, and "convenient for some but not all" was reiterated using many different factors in order to support these claims. Respondents cited lack of digital skills, lack of skills needed to use social media specifically, lack of access to a computer, and lack of access to an internet connection as conditions that might promote exclusion from neighborhood communication. Aside from digital literacy and/or digital access, some explanations for conditions of inclusion or exclusion were that fellow residents: might not be familiar with social media, are not interested in using or prefer not to use 
social networking sites, or do not have accounts. For example a reiterated response was, "No, not everyone owning a house in this neighborhood uses facebook or twitter and you would be leaving them out."

Several respondents mentioned that social media within the neighborhood might be a good secondary or supplemental source of information and communication, but would be insufficient if social networking sites were the primary form of communication. For example, residents responded in accordance with this comment: "I don't rely on electronic contacts - they are only effective if everyone can and will use them. Those who don't don't communicate if that is the only option." Or as another resident noted: "They [Facebook and Twitter] are limited forms of communication because not all people choose to use facebook and/or twitter. Other forms of communication probably would be superior." In some cases, respondents emphatically represented themselves as one of the residents who would be excluded by a shift to neighborhood communication via social media: "[Social media would] Probably [be a good way to communicate] if people know about it. But not everyone has a computer or belongs to facebook or tweets. I don't."

The most common hesitation or complaint about unequal access to social media for neighborhood communication was articulated through a discussion of age and life stage. Respondents tended to equate increased age with decreased knowledge and/or desire to use social media (or digital technologies in general). Residents identified themselves as old, retired, or ill and offered these conditions as reasons for not using computers or social media. For yes, no, maybe, and I don't know answers, the age of participants was frequently mentioned as a reason either to use (because you or other residents were young) or not to use (because you or other residents were old) social media. The mean age of the "Yes" respondents was 50, the "No" respondents' mean age was 63 while the means from the "Maybe's" and "Don't knows" were 56 and 72 respectively. Repeated sentiments among residents included: "It [social media] can be a good source of information except we have older neighbors that are not on the 
computer so they are left out. Neighborhood newsletters (sic) were more helpful." "I do not use facebook or twitter. I think mailing flyers is the best way. Many of our neighborhood is retired, online may not be utilized as often." "Yes, for younger people. I think that older residents would still need to get a phone call or something in the mail;" "Many older folks don't use Facebook and/or twitter." "The older people in the IHNA (me included) may not use these;" "Facebook and Twitter are the modern way of communicating among various people and organizations. However, older people (over 65-year) might not use the online method". "No - old people don't use the internet." In some cases people noted their age, life stage, or physical condition as a reason they were not able to assess or answer the write-in question: "infirmaties (sic) limit my ability to evaluate this", "age limits my ability to evaluate this", "In general yes [social media would be a good way to communicate], but we are retired and ill so no;".

\section{Discussion}

From a previous study with this data (Johnson \& Halegoua, 2013), we know that the Social Media members when compared to those who did not choose the social media options are younger, have children, are newer to the neighborhood, would be more involved if their work schedules and child care allowed, participate in civic activities, and are more trusting of the City of Lawrence government. Although other studies suggest that social media users have fewer neighborhood ties (Hampton, 2007) this was not the case with this study. A $t$ test $(t(120)=-$ $.334, p=.74)$ comparison of the Social Media group (mean $=3.16)$ and the Mail group (mean $=$ 3.23) indicated no significant difference in the number of people they had a neighborly relationship with (can borrow a tool, watch each other's houses when away) (1, None to 5, Almost everyone). This study shows that the Social Media group desires a neighborhood association more so than those who prefer other, more traditional, means of neighborhood communication (Email or Mail). Of particular note are those who chose the Mail option. The regression results indicate they are not that interested in having a neighborhood association. The most expensive way of communicating in a neighborhood is via mail. As previous 
researchers have explained, those seeking to use social media to connect with place-based communities need to be aware of limitations and rely on multiple means of communication. Relying on multiple communication methods is to ensure all groups are included. The results of this study indicate that multiple communication methods are still a good idea but targeting audiences with different types of communication would be best, particularly for resource poor organizations like the IHNA. The IHNA should think twice about using precious dollars to purchase the most expensive form of communication (mail) to reach those who are not that interested in a neighborhood organization anyway.

In addition to targeting resources and communication methods to the most receptive audiences, the responses to the open ended question provide further advice for how to make the most of the social media option and further limitations to consider. Other than general complaints, personal preferences against the use of social media, or the self-reported lack of computer access, Internet access, or digital skills, we found three main categories that were reiterated by residents in order to explain their lack of social media use within the community (and that are deserving of further research): a mismatch between "neighborly" ties and the more intimate ties associated with "friends" on social media, desires for an inclusive or representative neighborhood organization, and expectations regarding face-to-face communication within a neighborhood. These findings show the different roles of neighborhood organizations (social versus political or both).

How social people want a neighborhood association to be is shown in the discomfort some had with Facebook for neighborhood communication. The lack of perceived intimacy within the neighborhood emphasizes that the relationships and information shared on Facebook are more personal or intimate than would be shared with "neighbors" who were not also already friends. Propinquity does not, by itself, create a tie strong enough for access to online profiles that display social ties, status updates, personal information, and status updates (Wellman, 1988). This points to the use of Facebook specifically and indicates that perhaps a more 
“impersonal” online networking tool might be more appropriate until closer ties can be established through neighborhood events or activities.

Our findings show that there is a perception that neighborhood communication and participation should be egalitarian and inclusive. A neighborhood organization that relies on social media alone not only risks falling victim to digital divides and exclusion but also risks alienating those who would feel like the organization was not inclusive and fair to all. There was hesitation or resistance to social media use among respondents because they saw such platforms as privileged among youth, the tech savvy, people who owned a computer, and those who knew how to use social media. The perception that not all neighborhood members could access social media for information gathering and information sharing was a major concern for the majority of those answering the open ended question. This concern related to the role of a neighborhood organization as being representative and potentially politically active (a political role). IHNA was founded with the goal of being politically active and representative of neighborhood concerns. As a result, it makes sense that residents would be concerned about inclusivity whether they wanted to be social with neighbors or not.

Respondents returned to the idea that neighborhoods were about face to face meetings. Therefore, the neighborhood organization needed to utilize the context of the community and have events or activities where people could interact face to face. For those in the Social Media group as well as non-users, the combination of face to face events and online communication might prove particularly meaningful. This echoes some of Arnold, Gibbs, and Wright's (2003) study on a neighborhood intranet. The researchers noted that, ironically, residents tended to frequent face to face events about the development of online forums more frequently than the online forums themselves.

Urban planning literature about social media is generally positive about the implementation and activation of social media networks within neighborhoods and by neighborhood associations. Several urban planners and scholars have found success in social 
media and digital practices (like gaming) for participatory planning, gaining community input about planning initiatives, publicizing and attempting to engage a broader audience for their plans, or educating the public about planning projects in their area (Evans-Cowley, 2010; Fredericks \& Foth, 2012; Gordon \& Manosevitch, 2010; Gordon, Schirra, \& Hollander, 2011). These articles and projects reinforce the idea that social media is a useful way to solve the problem of connecting and communicating with a neighborhood when resources and neighborhood efficacy may be lacking.

However, using social media for participation in planning on a city level is different than on a neighborhood level and the same strategies for social media use might not apply. Planning issues based around an event or debates are different than communication and contact within a particular neighborhood. The former situation hails individuals as residents and citizens and asks for input, the other hails individuals on a personal level, as a neighbor, and asks people to connect with others. It makes sense that there would be some resistance in the latter example or concerns about whether Facebook and Twitter as the most appropriate platforms to communicate with neighbors. We agree with Foth's (2006b, p. 44) observation that it is necessary to design context and purpose-specific online tools that cater to both social and place-based experiences, the hybrid qualities of "community", and that the shift in context toward the local or hyperlocal may introduce new concerns pertaining to privacy and control.

Our findings contribute to these suggestions and debates by highlighting certain affordances, uses and norms of social networking sites that might not mesh with neighborhood communication practices, contexts, and preferences. For example, study participants mentioned the practice of only "friending" people they know well, neighbors they were already friends with, and maintaining relationships with neighbors that resemble "familiar strangers" (Milgram, 1977) rather than "friends". Additionally, issues related to social media and "context collapse", or the collapsing of multiple audiences (that are typically addressed distinctly) into a single context, as well as levels of intimacy also seem to be in tension with the neighborhood context (boyd, 2008; 
Marwick \& boyd, 2011). More participants in our study preferred email to social media as a means of communicating electronically. The attraction of email is that it doesn't offer visibility of profiles, friendship networks or social interactions. Nevertheless, the Email group was not as interested in having a neighborhood organization as the Social Media group. This reinforces the advice here which is to tailor communication but also to target likely populations. An email or a service that resembles a listserv, discussion forum, or messaging system that allows for minimal profile creation and no or low visibility of social ties might be most useful as a tool to activate a neighborhood when an issue arises (political role of a neighborhood organization) but might not be as effective as social media in creating social ties (social role of a neighborhood organization).

In a 2003 study of "The Range," a community intranet developed and implemented for a neighborhood of 100 households in Melbourne, Australia, Arnold, Gibbs, and Wright (2003) found that even after three years of implementation and promotion of the network and community forums residents use of the intranet and networked services was extremely low. The researchers offered five arguments to explain this low adoption rate. First, they questioned whether the scale and scope of the neighborhood was too small as compared to other placebased communities like the Blacksburg Electronic Village where residents' use of the intranet was considered successful. Second, the authors considered whether the types of sociality and communication enabled by the intranet discussion boards and forums disrupted other types of neighborhood sociality, and therefore was an "inappropriate" technology for neighborhood use (p. 192). Third, the authors argue that the definition of community is understood as more "egocentered" rather than place-based and suggest that an intranet based neighbor or neighborhood communication is fundamentally flawed (p. 196). However, Hampton, Lee, and Her (2011, p. 1046) dispute claims such as these by suggesting that place-based networks aren't being entirely replaced by person to person networks or "networked individualism", but that the use of social media within the neighborhood setting is one of the few contexts in which place-based 
relationships seem to have less resonance. Another reason why further research into social media use within neighborhoods, and the meeting of online and offline neighborhood relationships and practices are deserving of further interrogation. The fourth argument about low adoption rates on "The Range" is that the network was established from the top-down and was not seen as "organic" or part of "normal" everyday life (p. 198). Finally, the fifth reason given was that residents were not educated or were not able to familiarize themselves with the technology adequately, therefore the technology and its purpose remained elusive (p. 199). Gaved and Foth's (2006) findings reinforce several of these perspectives. The authors note that the most effective community digital, social networks are ones that cultivate and maintain a sense of ownership of the network; use simple, open-ended tools; is a top-down and bottom-up hybrid; and develops internal and/or external outlets for technical training and support.

Drawing on suggestions in the literature and refining them using results from this study, advice for the IHNA and similar neighborhood organizations is listed below. The advice is divided into categories based on the transactional framework (time, environment, and person). In regards to the component "time", the advice is as follows:

- Social media is convenient and quick for leaders and participants.

- Social media is timely and can reach neighbors quickly if any issues arise.

- If social media is used, it should not waste neighbors' time with superfluous postings. Perhaps the neighborhood association could pledge to residents that postings will be few, pertinent, but also humorous on occasion.

In the aspect of "environment" which also includes social context, the suggestions are:

- Particularly for a politically oriented neighborhood organization, be aware of the need to be representative and use multiple forms of communication.

- Particularly for a socially oriented neighborhood organization, do not wait too late until social ties are so low that using an easy, convenient form of communication like social media does not match the neighborhood any more. 
- Empowered organizations have regular activities and a formal structure and social media, email, mail, word of mouth, and doorhangers can be part of that structure which can then create synergy between online and offline connections especially through face-to-face activities, such as, the luminaria event, park clean-up days, a speakers series, ice cream socials, meet and greets with elected officials or city staff, and potlucks.

- Neighborhood organizations with larger boundaries may find social media useful for holding larger areas together where people in the same neighborhood do not see each other on the same block or street, but the problem of low sociability and hesitancy about joining a Facebook page with even "familiar strangers" is still an obstacle.

When looking to the right fit between the "person" and social media communication, keep the following in mind:

- $\quad$ The Social Media people may be few but "mighty" as they may be the ones most interested in a neighborhood association and willing to create social ties within their neighborhood.

- Low resource neighborhood organizations may want to start with social media (low cost, low time) and then build from there. Once connections are made, volunteers recruited, and resources are coming in, then moving out to more expensive means of communication can occur.

- Build in ownership of social media by asking participants to help manage the page or supply content.

- Email or listservs are a viable means of communication but neighborhood organizations should not wait until their neighborhood ties are so low that they no longer have valid email addresses. 
- Email addresses are key to having a low cost, convenient means of communication and are key to branching out to social media.

- $\quad$ Social ties are important to having the volunteers necessary to reach everyone with lower cost methods of communication (doorhangers or signs in the neighborhood). Social media and email can help recruit these volunteers.

- Social ties are also important to being able to reach out to neighbors to provide training in the use of email or social media.

- Social media users tend to be younger and have children which will mean accommodating children in neighborhood activities and being sensitive to work/time commitments.

- $\quad$ Mail is expensive and may not reach the most interested neighbors.

This set of advice is similar to that which has been proposed in regards to using multiple forms of communication, but this advice goes further to help neighborhood organizations prioritize resources and reach the most interested neighbors first and build from there.

There are limitations to this study. The findings represent only one neighborhood and thus are not generalizable. It is for future research to survey other neighborhoods and look for commonalities. Since the sample size was small, the number of variables that could be entered into the regression model at one time was limited. Plus, many of the variable were highly correlated which again limited the number that could be placed in a regression at any one time. In the open ended question about whether people thought Facebook and Twitter were good ways to communicate with the neighborhood, we left "neighborhood" open to interpretation and did not specify the neighborhood association. In the future, we hope to survey other neighborhoods about their use of social media and other forms of communication and to interview IHNA residents to delve deeper into participation rates and communication preferences. 


\section{Conclusion}

From this study we learned that the Social Media group is the population within the Indian Hills Neighborhood that would like to have a neighborhood organization. If it is the social media people who are most interested in a neighborhood association as well as social media as a communication tool, it seems beneficial to target members of this group to help develop an online network that they would be invested in. It is a common strategy in any new venture to start with "easy wins" and the Social Media group would be a good place for the IHNA to start. If they can get this group to connect via social media then IHNA will have an easy, low-cost way of reaching those most interested in a neighborhood organization. Since work and childcare were listed as reasons that interfere with neighborhood involvement, it is possible that members of the social media group would be willing to serve as administrators for neighborhood social media sites or other online networking tools. Once this group is involved, IHNA can move to other organizing and mobilizing strategies that involve volunteers (one-to-ones) and money (mailings, doorhangers). While interactions and information dissemination via social media might end up as a supplement to other forms of communication, face to face interaction, and events, it might prove to be a good way to "jumpstart" a failing or flailing neighborhood association. The tricky part of this strategy is to not alienate those who see social media communication as unfair.

There is hope for the use of social media in a neighborhood context, but as other researchers have found, that hope is contingent. With this study we have further defined those contingencies, but have clarified how neighborhood organizations can be strategic about their social media use and outreach. While writing this paper, one of the authors responded to a question on the IHNA Facebook page. The resident was inquiring about the date of the annual neighborhood garage sale. The response said that the garage sale day was up in the air and dependent on getting people to set it up and advertise it. The resident was asked if she would like to help. She messaged back, "Ok thanks. I will try to help out if possible." It is a start. 
Although Indian Hills residents were hesitant about joining the social media networks set up by the steering committee, our preliminary findings on populations who would like to use social media to communicate with neighbors point to a good source of potential neighborhood organization members and provide information on how to re-advertise the social media and email options in the future. The recent message posted on the IHNA Facebook page demonstrates the potential to turn online ties into offline connections. It is important to recognize that bringing offline and online communication methods, information grounds, and experiences together will be key to rebuilding the IHNA starting with social media users and moving to non-social media users and hopefully breathing new life into a 39 year old organization. 


\section{References}

Altman, I., \& Rogoff, B. (1987). World views in psychology: Trait, interactional, organismic, and transactional perspectives. In D. Stokols \& I. Altman (Eds.), Handbook of Environmental Psychology (Vol. 1, pp. 1-40). New York: Wiley.

Arnold, M. (2003). Intranets, Community, and Social Capital: The Case of William Bay. Bulletin of Science Technology and Society, 23(2), 78-87.

Arnold, M., Gibbs, M., \& Wright, P. (2003). Intranets and Local Community: 'Yes, an intranet is all very well, but do we still get free beer and a barbeque?'. In M. Huysman, E. Wenger \& V. Wulf (Eds.), Communities and Technologies (pp. 185-204): Springer Netherlands.

Arnold, M., Gibbs, M. R., \& Wright, P. (2003). Intranets and Local Community: Yes, an intranet is all very well, but do we still get free beer and barbeque? In M. Huysman, E. Wenger \& V. Wulf (Eds.), Communities and Technologies (pp. 185-204). Dordecht: Kluwer Academic Publishers.

Backman, E. V., \& Smith, S. R. (2000). Healthy Organizations, Unhealthy Communities? Nonprofit Management \& Leadership, 10(4), 355-373.

Ball-Rokeach, S. J., Kim, Y.-C., \& Matei, S. (2001). Storytelling neighborhood: Paths to belonging in diverse urban environments. Communication Research, 28(4), 392-428.

boyd, d. (2008). Taken Out of Context: American Teen Sociality in Networked Publics. PhD Dissertation. University of California-Berkeley, School of Information.

Brown, B. B., \& Cropper, V. L. (2007). New Urban and Standard Suburban Subdivisions: Evaluating Psychological and Social Goals. Journal of the American Planning Association, 67(4), 402-419.

Carroll, J. M. (2012). The Neighborhood in the Internet: Design Research Projects in Community Informatics. New York: Routledge.

Carroll, J. M., \& Rosson, M. B. (2003). A Trajectory for Community Networks. The Information Society: An International Journal, 19(5), 381-393.

Chavis, D. M., \& Wandersman, A. (1990). Sense of Community in the Urban Environment: A Catalyst for Participation and Community Development. American Journal of Community Psychology, 18(1), 55-81.

Chen, N.-T. N., Dong, F., Ball-Rokeach, S. J., Parks, M., \& Huang, J. (2012). Building a new media platform for local storytelling and civic engagement in ethnically diverse neighborhoods. New Media \& Society, 14(6), 931-950. doi: 10.1177/1461444811435640

Christens, B. D. (2010). Public Relationship Building in Grassroots Community Organizing: Relational Interventions for Individual and Systems Change. Journal of Community Psychology, 38(7), 896-900.

Cooperrider, D., \& Avital, M. (Eds.). (2004). Constructive Discourse and Human Organization: Advances in Appreciative Inquiry: Elsevier Publishing.

Coulton, C. J., Jennings, M. Z., \& Chane, T. (2012). How Big is My Neighborhood? Individual and Contextual Affects on Perceptions of Neighborhood Scale. American Journal of Community Psychology, 51(1-2), 40-50.

Cresswell, J. (2007). Qualitative Inquiry and Research Design: Choosing Among Five Approaches. Thousand Oaks, CA: Sage Publications.

De Cindio, F., Gentile, O., Grew, P., \& Redolfi, D. (2003). Community Networks: Rules of Behavior and Social Structure. The Information Society: An International Journal, 19(5), 395-406.

Dillman, D. A. (2000). Mail and Internet Surveys (Second ed.). New York: John Wiley \& Sons, Inc. 
Doolittle, R. J., \& MacDonald, D. (1978). Communication and a Sense Of Community in a Metropolitan Neighborhood: a Factor Analytic Examination. Communication Quarterly, 26(3), 2-7.

Ellison, N., Steinfield, C., \& Lampe, C. (2006). Spatially Bounded Online Social Networks and Social Capital: The Role of Facebook. Paper presented at the International Communication Association, Dresden.

Evans-Cowley, J. S. (2010). Planning in the age of Facebook: the role of social networking in planning processes. GeoJournal, 75, 407-420.

Evans-Cowley, J. S., \& Hollander, J. (2010). The New Generation of Public Participation: Internet-based Participation Tools. Planning, Practice \& Research, 25(3), 397-408.

Florin, P., \& Wandersman, A. (1990). An Introduction to Citizen Participation, Voluntary Organizations, and Community Development: Insights for Empowerment Through Research. American Journal of Community Psychology, 18(1), 41-54.

Foth, M. (2006a). Analyzing the Factors Influencing the Successful Design and Uptake of Interactive Systems to Support Social Networks in Urban Neighborhoods. International Journal of Technology and Human Interaction, 2(2), 65-79.

Foth, M. (2006b). Facilitating Social Networking in Inner-City Neighborhoods. IEEE Computer, 39(9).

Foth, M., \& Brereton, M. (2004). Enabling local interaction and personalised networking in residen- tial communities through action research and participatory design. Paper presented at the OZCHI 2004: Supporting community interaction, Wollongong, NSW: University of Wollongong.

Fredericks, J., \& Foth, M. (2012). Augmenting public participation: enhancing planning outcomes through the use of social media and web 2.0. Australian Planner.

Gaved, M., \& Foth, M. (2006). More than wires, pipes and ducts: some lessons from grassroots networked communities and master-planned neighbourhoods. Paper presented at the OTM (OnTheMove) Workshops.

Glynn, T. J. (1981). Psychological Sense of Community: Measurement and Application. Human Relations, 34(7), 789-818.

Gordon, E., \& Manosevitch, E. (2010). Augmented Deliberation: Merging Physical and Virtual Interaction to Engage Communities in Urban Planning. New Media \& Society, 13(1), 7595.

Gordon, E., Schirra, S., \& Hollander, J. (2011). Immersive Planning: A Conceptual Model for Designing Public Participation with New Technologies. Environment and Planning B: Planning and Design, 38(3), 505-519.

Gurstein, M. (2004). Welcome to the Journal of Community Informatics. The Journal of Community Informatics, 1(1).

Hampton, K. (2003). Grieving For A Lost Network: Collective Action Online in a Wired Suburb. The Information Society, 19, 417-428.

Hampton, K. (2007). Neighborhoods in the Network Society the e-Neighbors study. Information, Communication \& Society, 10(5), 714-748. doi: 10.1080/13691180701658061

Hampton, K., Lee, S., \& Her, E. (2011). How New Media Affords Network Diversity: Direct and Mediated Access to Social Capital Through Participation in Local Social Settings. New Media \& Society, 13(7), 1031-1049.

Hampton, K., \& Wellman, B. (1999). Netville Online and Offline: Observing and Surveying a Wired Suburb. American Behavioral Scientist.

Hampton, K., \& Wellman, B. (2003). Neighboring in Netville: How the Internet Supports Community and Social Capital in a Wired Suburb. City \& Community, 2(4), 277-311.

Hampton, K. N. (2003). Grieving for a Lost Network: Collective Action in a Wired Suburb Special Issue: ICTs and Community Networking. The Information Society, 19(5), 417-428. doi: 10.1080/714044688 
Hampton, K. N. (2007). Neighborhoods in the Network Society. Information, Communication \& Society, 10(5), 714-748.

Hesse, B. W., Werner, C. M., \& Altman, I. (1988). Temporal Aspects of Computer-Mediated Communication. Computers and Human Bahavior, 4, 147-165.

Hillier, J. (2002). Presumptive Planning: From Urban Design to Community Creation in One Move? In A. T. Fisher, C. C. Sonn \& B. J. Bishop (Eds.), Psychological Sense of Community: Research, Applications, and Implications (pp. 43-67). New York: Kluwer Adademic/ Plenum Publishers.

Hollan, J., \& Stornetta, S. (1992). Beyond Being There. Paper presented at the CHI '92 Proceedings of the SIGCHI Conference on Human Factors in Computing Systems.

Indian Hills Neighborhood Association. (1974). IHNA Meeting Minutes. Lawrence, KS: Indian Hills Neighborhood Association Archives.

Indian Hills Neighborhood Association. (1985). History of Indian Hills. Lawrence, KS: Indian Hills Neighborhood Association Archives.

Indian Hills Neighborhood Association. (1998). Note on History of Indian Hills. Lawrence, KS: Indian Hills Neighborhood Association Archives.

Indian Hills Neighborhood Association. (2003). Indian Hills Neighborhood Association Brochure. Lawrence, KS: Indian Hills Neighborhood Archives.

Indian Hills Neighborhood Association. (2004). Luminaria Newsletter Item. Lawrence, KS: Indian Hills Neighborhood Association Archives.

Itzhaky, H. (1995). Can social work intervention increase organizational effectiveness? International Social Work, 38, 277-286.

Johnson, B. J., \& Halegoua, G. (2013). Potential and Challenges for Social Media in the Neighborhood Context. Paper presented at the Symposium on Urban Informatics: Exploring Smarter Cities, Drexel University, Philadelphia, PA.

Kavanaugh, A., \& Patterson, M. (2002). The Impact of Community Computer Networks on Social Capital and Community Involvement in Blacksburg. In B. Wellman \& C. Haythornthwaite (Eds.), The Internet in Everyday Life. Malden, MA: Blackwell.

Kavanaugh, A. L., Zin, T. T., Rosson, M. B., Carroll, J. M., Schmitz, J., \& Kim, B. J. (2007). Local Groups Online: Political Learning and Participation. Computer Supported Cooperative Work, 16, 375-395.

Kim, B. J., Kavanaugh, A. L., \& Hult, K. M. (2007). Local Community Groups and Internet Use. International Journal of Technology, Knowledge and Society, 2(7), 207-221.

Kim, B. J., Kavanaugh, A. L., \& Hult, K. M. (2011). Civic Engagement and Internat Use in Local Governance: Hierarchical Linear Models for Understanding the Role of Local Community Groups. Administration and Society, 43(7), 807-835.

Kim, Y.-C., \& Ball-Rokeach, S. J. (2006). Community storytelling network, neighborhood context, and civic engagement: A multilevel approach. Human Communication Research 32(4), 411-439.

Kotler, M. (1969). Neighborhood Government: The Local Foundations of Political Life. Indianapolis: The Bobbs-Merril Co.

Looker, B. (2010). Microcosms of Democracy: Imagining the City Neighborhood in World War IIEra America. Journal of Social History, 44(2), 351-378.

Lopes, S. (2001). Building Community Power Structures, 1984-1998: The Rise of Grassroots Neighborhood Influence. In D. Domer \& B. Watkins (Eds.), Embattled Lawrence: Conflict \& Community (pp. 277-288). Lawrence, KS: University of Kansas.

Mandarano, L., Meenar, M., \& Steins, C. (2010). Building Social Capital in the Digital Age of Civic Engagement. Journal of Planning Literature, 25(2), 123-135.

Martinez, M. L., Black, M., \& Starr, R. H. (2002). Factorial Structure of the Perceived Neighborhood Scale (PNS): A Test of Longitudinal Invariance. Journal of Community Psychology, 30(1), 23-43. 
Marwick, A., \& boyd, d. (2011). I Tweet Honestly, I Tweet Passionately: Twitter Users, Context Collapse, and the Imagined Audience. New Media and Society, 13, 96-113.

McClenahan, B. A. (1929). The Changing Urban Neighborhood, From Neighbor to Nigh-dweller. Los Angeles, CA: University of Southern California Studies.

McKenzie, R. D. (1921). The Neighborhood: A Study of Local Life in the City of Columbus, Ohio. II. American Journal of Sociology, 27(3), 344-363. doi: 10.2307/2764546

McKenzie, R. D. (1922). The Neighborhood: A Study of Local Life in the City of Columbus, Ohio - - Concluded. American Journal of Sociology, 27(6), 780-799.

Meredith, D., Ewing, S., \& Thomas, J. (2004). Neighbourhood Renewal and Government by Community: The Atherton Gardens Network. International Journal of Cultural Policy, 10(1), 85- 101.

Milgram, S. (1977). The individual in a social world : essays and experiments. Reading, MA: Addison-Wesley Pub. Co.

Ohmer, M. L. (2008). The Relationshiop Between Members' Perceptions of Their Neighborhood Organization and Their Involvement and Perceived Benefits from Participation. Journal of Community Psychology, 36(7), 851-870.

Olson, P. (1982). Urban Neighborhood Research: Its Development and Current Focus. Urban Affairs Review, 17(4), 491-518.

Pattavina, A., Pierce, G., \& Saiz, A. (2002). Urban Neighborhood Information Systems: Crime Prevention and Control Applications. Journal Of Urban Technology, 9(1), 37-56.

Perkins, D. D., \& Long, A. D. (2002). Neighborhood Sense of Community and Social Capital: A Multi-Level Analysis. In A. T. Fisher, C. C. Sonn \& B. J. Bishop (Eds.), Psychological Sense of Community: Research, Applications, and Implications (pp. 291-318). New York: Kluwer Academic/ Plenum Publishers.

Peterson, N. A., Speer, P. W., Hughey, J., Armstead, T. L., Schneider, J., E., \& Sheffer, M. A. (2008). Community Organizations and Sense of Community: Further Development in Theory and Measurement. Journal of Community Psychology, 36(6), 798-813.

Pigg, K., \& Crank, L. (2004). Building Community Social Capital: The Potential and Promise of Information and Communications Technologies. The Journal of Community Informatics, 1(1), 58-73.

Pinkett, R. (2003). Community Technology and Community Building: Early REsults from the Creating Community Connections Project. The Information Society: An International Journal, 19(5), 365-379.

Postill, J. (2008). Localizing the Internet Beyond Communities and Networks. New Media \& Society, 10(3), 413-431.

Postman, N. (1999). Technopoly: the surrender of culture to technology. New York: Vintage Books.

Putnam, R. D. (2000). Bowling Alone: The Collapse and Revival of American Community. New York: Simon \& Schuster.

Riger, S., \& Lavrakas, P. J. (1981). Community Ties: Patterns of Attachment and Social Interaction in Urban Neighborhoods. American Journal of Community Psychology, 9(1), 55-66.

Roberts, L., Smith, L., \& Pollock, C. (2002). MOOing Till the Cows Come Home: The Search for Sense of Community in Virtual Enivronments. In A. T. Fisher, C. C. Sonn \& B. J. Bishop (Eds.), Psychological Sense of Community: Research, Applications, and Implications (pp. 223-245). New York: Kluwer Academic/ Plenum Publishers.

Saguaro Seminar. (2000). 2000 Social Capital Benchmark Survey Retrieved August, 2005, from http://www.ropercenter.uconn.edu/scc bench.html

Schuler, D. (1996). New Community Networks: Wired for Change: Addison-Wesley Publishing Company. 
Shah, D. V., Kwak, N., \& Holbert, R. L. (2001). 'Connecting' and 'Disconnecting' with Civic Life: Patterns of Internet Use and the Production of Social Capital. Political Communication, 18, 141-162.

Sigmon, S. T., Whitcomb, S. R., \& Snyder, C. R. (2002). Psychological Home. In A. T. Fisher, C. C. Sonn \& B. J. Bishop (Eds.), Psychological Sense of Community (pp. 25-42). New York: Kluwer Academic/ Plenum Publishers.

Silver, C. (1985). Neighborhood Planning in Historical Perspective. Journal of the American Planning Association, 51(2), 161-174.

Smith, A. (2010). Neighbors Online, Pew Internet and American Life Project.

Strauss, A., \& Corbin, J. (1990). Basics of Qualitative Research: Grounded Theory Procedures and Techniques. Newbury Park, CA: Sage Publications.

Tannenbaum, J. (1948). The Neighborhood: A Socio-Psychological Analysis. Land Economics, 24(4), 358-369.

Taylor, R. B. (2012). Defining Neighborhoods in Space and Time. Cityscape: A Journal of Policy Development and Research, 14(2), 225-230.

Taylor, R. B., Gottfredson, S. D., \& Brower, S. (1984). Neighborhood Naming as an Index of Attachment to Place. Population and Environment, 7(2, Special Issue on Attachment to Place), 103-125.

Unger, D. G., \& Wandersman, A. (1985). The Importance of Neighbors: The Social, Cognitive, and Affective Components of Neighboring. American Journal of Community Psychology, 13(2), 139-169.

Warren, D. I. (1977). The Functional Diversity of Urban Neighborhoods. Urban Affairs Review, 13(2), 151-180.

Wellman, B. (1988). The community question re-evaluated. In M. P. Smith (Ed.), Power, community and the city. New Brunswick, NJ: Transaction Books.

Wellman, B. (1999). Ties and Bonds. Connections, 22(1), 12-18.

Wellman, B., \& Hampton, K. (1999). Living Networked On and Off Line. Contemporary Sociology, 28(6), 648-654.

Werner, C. M., Brown, B. B., \& Altman, I. (2002). Transactionally Oriented Research: Examples and Strategies. In R. B. Bechtel \& A. Churchman (Eds.), Handbook of Environmental Psychology (pp. 203-221). New York: John Wiley \& Sons, Inc. 
Map 1 - City of Lawrence and Neighborhood Location

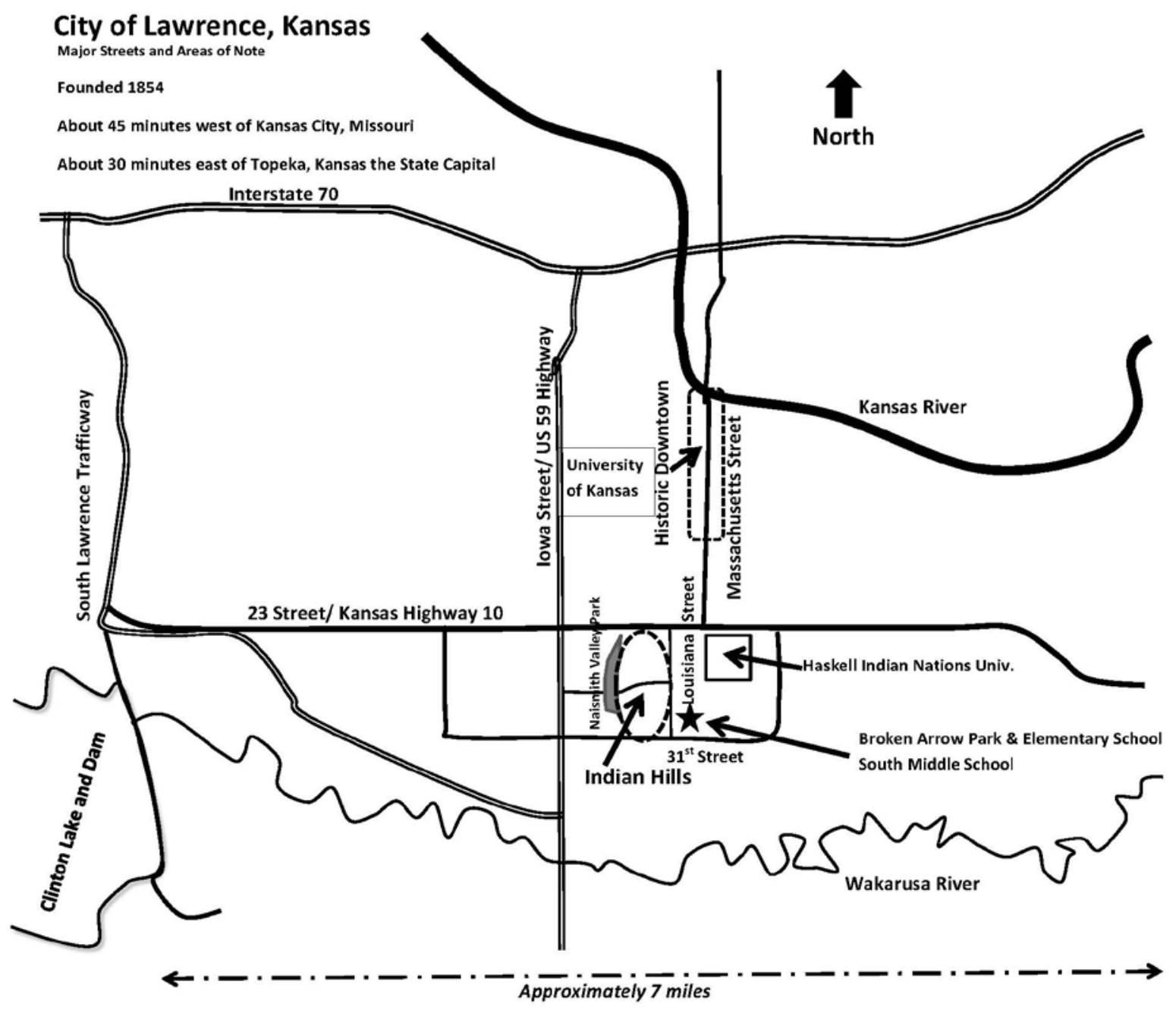


Table 1 - Demographic Comparison City of Lawrence and Indian Hills, 2010 Census Data

\begin{tabular}{|l|l|l|}
\hline & Lawrence & Indian Hills \\
\hline Population & 87,643 & 1,527 \\
\hline Female & $50 \%$ & $51 \%$ \\
\hline Male & $50 \%$ & $49 \%$ \\
\hline Age & & \\
\hline Under 18 & $18 \%$ & $23 \%$ \\
\hline 65 or over & $8 \%$ & $15 \%$ \\
\hline Race & & \\
\hline $\begin{array}{l}\text { American Indian, Alaskan } \\
\text { Native, Native Hawaiian, } \\
\text { Pacific Islander }\end{array}$ & $3 \%$ & $3 \%$ \\
\hline Asian & $5 \%$ & $1 \%$ \\
\hline African American & $5 \%$ & $4 \%$ \\
\hline Some other race & $2 \%$ & $1 \%$ \\
\hline Two or more races & $4 \%$ & $5 \%$ \\
\hline White & $82 \%$ & $85 \%$ \\
\hline Ethnicity & & \\
\hline Hispanic & $6 \%$ & $5 \%$ \\
\hline Households & & \\
\hline Average Household Size & 2.28 & 2.43 \\
\hline Occupied Housing Units & $93 \%$ & $96 \%$ \\
\hline Owner Occupied Units & $47 \%$ & $69 \%$ \\
\hline Renter Occupied Units & $53 \%$ & $31 \%$ \\
\hline $\begin{array}{l}\text { Source: 2010 U.S. Census } \\
\text { Note - Percentages may not add up to 100 due to } \\
\text { rounding. }\end{array}$ & \\
\hline
\end{tabular}


Map 2 - Indian Hills Neighborhood Boundaries

(Source: City of Lawrence, Kansas, Planning and Development Service Department)

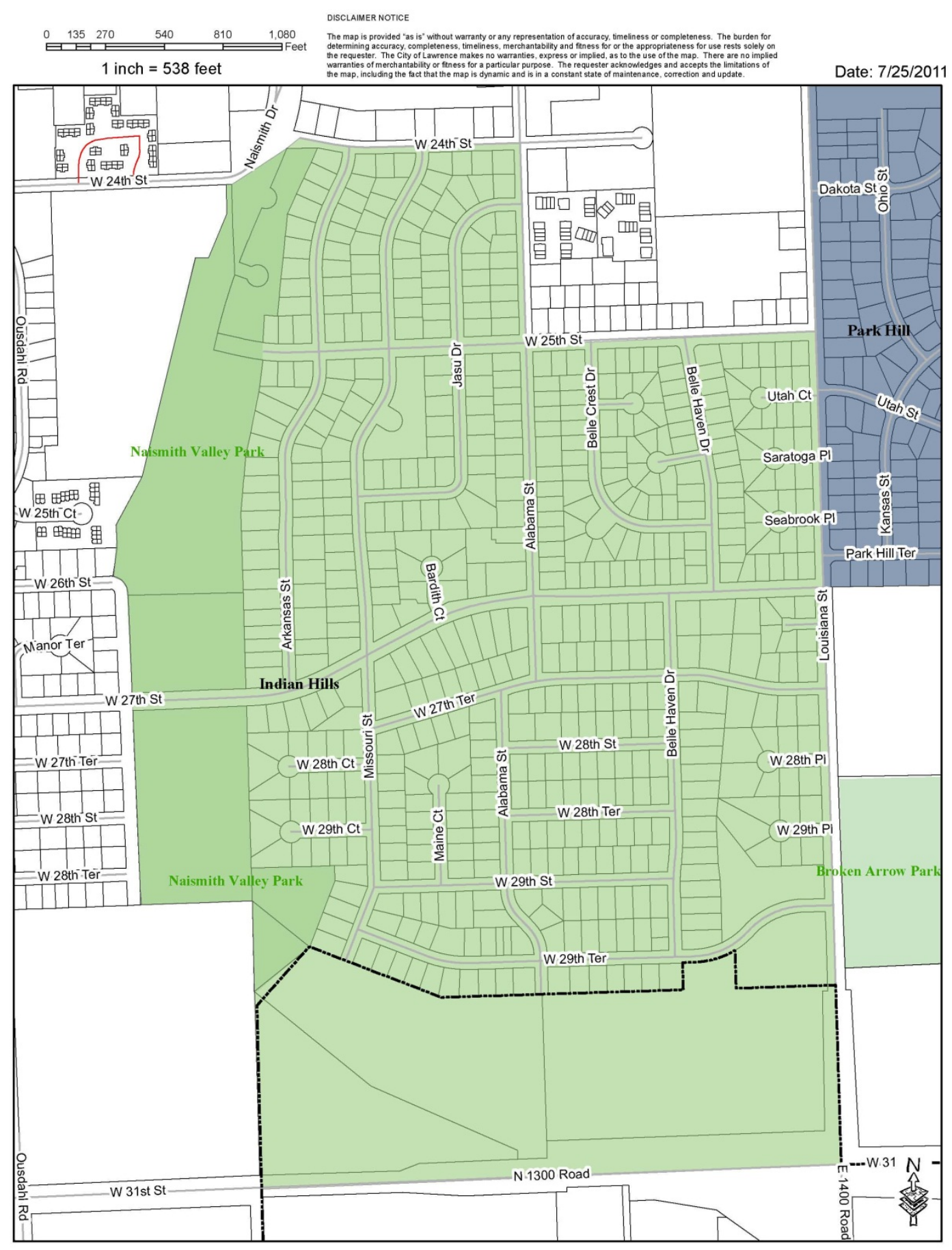


Table 2 - Descriptive Statistics of Variables

\begin{tabular}{|c|c|c|c|c|c|}
\hline Variable & Survey Item & Minimum & Maximum & Mean & $\begin{array}{l}\text { Standard } \\
\text { Deviation }\end{array}$ \\
\hline $\begin{array}{l}\text { Neighborhood } \\
\text { Organization }\end{array}$ & $\begin{array}{l}\text { My neighborhood should have a neighborhood } \\
\text { organization.* }\end{array}$ & 1 & 5 & 3.69 & .93 \\
\hline \multicolumn{6}{|l|}{ Time } \\
\hline $\begin{array}{l}\text { Future } \\
\text { Residency }\end{array}$ & $\begin{array}{l}\text { Do you expect to be in this residence for at least } \\
5 \text { more years? } 1=\text { No, } 2 \text { = Don't know, } 3=\text { Yes }\end{array}$ & 1 & 3 & 2.43 & .75 \\
\hline \multicolumn{6}{|l|}{ Environment } \\
\hline $\begin{array}{l}\text { Neighborhood } \\
\text { Boundaries }\end{array}$ & $\begin{array}{l}\text { What area do you define as your neighborhood? } \\
1=\text { the } 2 \text { or } 3 \text { houses immediately adjacent to my } \\
\text { house. } 2=\text { The } 5 \text { to } 10 \text { houses next to my house } \\
\text { and immediately across the street. } 3=\text { The } 20 \text { or } \\
\text { so houses on my street and nearby streets. } 4= \\
\text { The houses within the Indian Hills Neighborhood } \\
\text { Association area. } 5=\text { The houses in the Broken } \\
\text { Arrow Elementary School area. }\end{array}$ & 1 & 5 & 3.39 & 1.16 \\
\hline $\begin{array}{l}\text { Trust City of } \\
\text { Lawrence }\end{array}$ & $\begin{array}{l}\text { The City of Lawrence government is run for the } \\
\text { benefit of all the people.* }\end{array}$ & 1 & 5 & 2.88 & 1.21 \\
\hline Trust IHNA & I can trust the IHNA to do what is right.* & 1 & 5 & 3.31 & .88 \\
\hline Issues & $\begin{array}{l}\text { There are no serious issues in the } \\
\text { neighborhood.* }\end{array}$ & 1 & 5 & 3.16 & 1.10 \\
\hline $\begin{array}{l}\text { Neighborhood } \\
\text { Efficacy }\end{array}$ & $\begin{array}{l}\text { If there was a serious problem in this } \\
\text { neighborhood, the people here could get } \\
\text { together and solve it. }\end{array}$ & 1 & 5 & 3.38 & .83 \\
\hline \multicolumn{6}{|l|}{ Person } \\
\hline $\begin{array}{l}\text { Neighborhood } \\
\text { Does Well }\end{array}$ & $\begin{array}{l}\text { It is important to me that my neighborhood do } \\
\text { well. }\end{array}$ & 2 & 5 & 4.22 & .73 \\
\hline $\begin{array}{l}\text { Neighborly } \\
\text { Relationships }\end{array}$ & $\begin{array}{l}\text { Think about the people who live on your block or } \\
\text { cul-de-sac. How many people do you have a } \\
\text { neighborly relationship with (can borrow a tool, } \\
\text { watch each other's houses when away)? } 1 \text { = } \\
\text { None, } 5 \text { = Almost everyone }\end{array}$ & 1 & 5 & 3.03 & 1.18 \\
\hline \multirow[t]{2}{*}{ Income } & $\begin{array}{l}\text { If you added together the yearly incomes, before } \\
\text { taxes, of all the members of your household for } \\
\text { last year what would the total be? } 1=\text { Less than } \\
\$ 30,000,2=\$ 30,000 \text { but less than } \$ 50,000,3= \\
\$ 50,000 \text { but less than } \$ 75,000,4=\$ 75,000 \text { but } \\
\text { less than } \$ 100,000,5=\$ 100,000 \text { or more }\end{array}$ & 1 & 5 & 3.37 & 1.31 \\
\hline & & $\%$ & $\%$ & & Total \\
\hline $\begin{array}{l}\text { Social Media } \\
\text { Chosen }\end{array}$ & $\begin{array}{l}\text { Check the three best ways for the neighborhood } \\
\text { to communicate with you. (Facebook or Google+ } \\
\text { or Twitter chosen but not email or mail). }\end{array}$ & $1(23 \%)$ & $0(77 \%)$ & & 212 \\
\hline Email Chosen & $\begin{array}{l}\text { Check the three best ways for the neighborhood } \\
\text { to communicate with you. (Email chosen but not } \\
\text { social media or mail). }\end{array}$ & $1(36 \%)$ & 0 (64\%) & & 212 \\
\hline Mail Chosen & $\begin{array}{l}\text { Check the three best ways for the neighborhood } \\
\text { to communicate with you. (Mail chosen but not } \\
\text { social media or email). }\end{array}$ & $1(31 \%)$ & $0(69 \%)$ & & 212 \\
\hline
\end{tabular}


Table 3 - Multiple Regression of Neighborhood Organization Measure on Selected Measures Related to Time, Environment, and Person Characteristics

\begin{tabular}{|c|c|c|c|c|}
\hline & \multicolumn{2}{|c|}{ Unstandardized Coefficients } & \multirow{2}{*}{$\begin{array}{c}\text { Standardized } \\
\text { Coefficients } \\
\text { Beta } \\
\end{array}$} & \multirow[b]{2}{*}{$\mathrm{t}$} \\
\hline & $B$ & Std. Error & & \\
\hline Constant & -.198 & .508 & & -.698 \\
\hline \multicolumn{5}{|l|}{ Time } \\
\hline Future Residency & -.027 & .079 & -.024 & -.346 \\
\hline \multicolumn{5}{|l|}{ Environment } \\
\hline Neighborhood Boundaries & .026 & .055 & .032 & .470 \\
\hline Trust City of Lawrence & .043 & .056 & .053 & .771 \\
\hline Issues & -.039 & .061 & -.044 & -.642 \\
\hline Neighborhood Efficacy & $.226^{\star \star}$ & .087 & .195 & 2.592 \\
\hline \multicolumn{5}{|l|}{ Person } \\
\hline Trust IHNA & $.193^{\star \star}$ & .076 & .174 & 2.533 \\
\hline Neighborhood Does Well & $.528^{\star \star \star}$ & .091 & .412 & 5.791 \\
\hline Neighborly Relationships & .005 & .055 & .007 & .099 \\
\hline Income & .071 & .050 & .099 & 1.415 \\
\hline
\end{tabular}


Table 4 - Parsimonious Model, Multiple Regression of Neighborhood Organization Measure on Selected Measures Related to Environment and Person Characteristics

\begin{tabular}{|l|c|c|c|c|}
\hline & \multicolumn{2}{|l|}{ Unstandardized Coefficients } & $\begin{array}{l}\text { Standardized } \\
\text { Coefficients }\end{array}$ & \\
\hline & $\mathrm{B}$ & Std. Error & Beta & $\mathrm{t}$ \\
\hline Constant & .004 & .362 & & .012 \\
\hline Environment & & & & \\
\hline Neighborhood Efficacy & $.238^{\star \star \star}$ & .068 & .210 & 3.488 \\
\hline Person & & & & \\
\hline Trust IHNA & $.320^{\star \star \star}$ & .063 & .302 & 5.058 \\
\hline Neighborhood Does Well & $.433^{\star \star *}$ & .077 & .341 & 5.599 \\
\hline $\mathrm{R}^{2}=.36 \quad \mathrm{~F}=36.39$ Sig. $=.00 \mathrm{n}=196$ \\
\hline${ }^{\star * *} \mathrm{p} \leq 0.001$
\end{tabular}


Table 5 - Multiple Regression of Neighborhood Organization Measure on Selected Measures Related to Environment and Person Characteristics Plus Communication by Social Media

\begin{tabular}{|l|c|c|c|c|}
\hline & \multicolumn{2}{|l|}{ Unstandardized Coefficients } & $\begin{array}{c}\text { Standardized } \\
\text { Coefficients }\end{array}$ & \\
\hline & $\mathrm{B}$ & Std. Error & Beta & $\mathrm{t}$ \\
\hline Constant & .012 & .357 & & .034 \\
\hline Environment & & & & \\
\hline Neighborhood Efficacy & $.220^{\star \star \star}$ & .068 & .194 & 3.25 \\
\hline Person & & & .309 & 5.249 \\
\hline Trust IHNA & $.327^{\star \star \star}$ & .062 & .331 & 5.516 \\
\hline Neighborhood Does Well & $.421^{\star * *}$ & .076 & .150 & 2.623 \\
\hline Social Media & $.321^{\star *}$ & .122 & & \\
\hline $\mathrm{R}^{2}=.38 \quad \mathrm{~F}=29.84 \quad$ Sig. $=.00 \mathrm{n}=196$ \\
\hline${ }^{* * *} \mathrm{p} \leq 0.001,{ }^{* *} \mathrm{p}<0.05$
\end{tabular}


Table 6 - Multiple Regression of Neighborhood Organization Measure on Selected Measures Related to Environment and Person Characteristics Plus Communication by Email

\begin{tabular}{|l|c|c|c|c|}
\hline & \multicolumn{2}{|l|}{ Unstandardized Coefficients } & $\begin{array}{c}\text { Standardized } \\
\text { Coefficients }\end{array}$ & \\
\hline & $\mathrm{B}$ & Std. Error & Beta & $\mathrm{t}$ \\
\hline Constant & .003 & .363 & & .009 \\
\hline Environment & & & & \\
\hline Neighborhood Efficacy & $.239^{\star \star \star}$ & .069 & .211 & 3.476 \\
\hline Person & & & & \\
\hline Trust IHNA & $.320^{\star \star \star}$ & .064 & .302 & 5.018 \\
\hline Neighborhood Does Well & $.434^{\star * *}$ & .078 & .341 & 5.585 \\
\hline Email & -.012 & .112 & -.006 & -.109 \\
\hline $\mathrm{R}^{2}=.36 \quad \mathrm{~F}=27.15$ Sig. $=.00 \mathrm{n}=196$ \\
\hline${ }^{* * *} \mathrm{p} \leq 0.001,{ }^{* *} \mathrm{p}<0.05$
\end{tabular}


Table 7 - Multiple Regression of Neighborhood Organization Measure on Selected Measures Related to Environment and Personal Characteristics Plus Communication by Mail

\begin{tabular}{|c|c|c|c|c|}
\hline & \multicolumn{2}{|c|}{ Unstandardized Coefficients } & \multirow{2}{*}{$\begin{array}{c}\text { Standardized } \\
\text { Coefficients } \\
\text { Beta }\end{array}$} & \multirow[b]{2}{*}{$\mathrm{t}$} \\
\hline & $B$ & Std. Error & & \\
\hline Constant & .098 & .364 & & .268 \\
\hline \multicolumn{5}{|l|}{ Environment } \\
\hline Neighborhood Efficacy & $227^{\star \star \star}$ & .068 & 201 & 3.329 \\
\hline \multicolumn{5}{|l|}{ Person } \\
\hline Trust IHNA & $.318^{\star \star \star}$ & .063 & .300 & 5.061 \\
\hline Neighborhood Does Well & $.436 * \star \star$ & .077 & .343 & 5.660 \\
\hline Mail & $-.21^{\star}$ & .117 & -.103 & -1.789 \\
\hline \multicolumn{5}{|c|}{$R^{2}=.37 \quad F=28.40 \quad$ Sig. $=.00 \quad n=196$} \\
\hline
\end{tabular}

